\title{
Upaya Kepala Sekolah dalam Meningkatkan Pembelajaran Guru di Era Revolusi Industri 4.0
}

\author{
Indah Puspitaningtyas; Ali Imron; Maisyaroh \\ Manajemen Pendidikan Fakultas Ilmu Pendidikan Universitas Negeri Malang \\ Jl. Semarang no. 5 Malang \\ indahpuspitaningtyas0302@gmail.com
}

Article received: October 2020; revised : February 2020 ; accepted : March 2020

DOI : $10.17977 /$ um025v4i32020p165

\begin{abstract}
Education in Indonesia has entered the era of industrial revolution 4.0. Changes that occur are becoming more comprehensive and challenges are also increasingly global. In order to answer Indonesian education entering the industrial revolution era 4.0 the learning done by teachers must also change and improve and improve its quality. The implementation of supervision in accordance with the industrial revolution era will give birth to teachers and the appropriate quality of learning. Therefore principals must increasingly improve the quality of their competence in carrying out supervision of learning and can increasingly facilitate learners achieving learning goals.
\end{abstract}

Keyword: industrial revolution, competency of principals, supervision

\begin{abstract}
Abstrak: Penelitian ini bertujuan untuk mengungkap upaya yang dilakukan oleh kepala sekolah dalam meningkatkan pembelajaran guru di era revolusi industri 4.0. Upaya kepala sekolah dalam meningkatkan pembelajaran guru harus sesuai dan tepat dengan tujuan belajar peserta didik. Penelitian ini menggunakan metode kualitatif dengan analisis kualitatif deskriptif. Hasilnya menunjukkan bahwa upaya kepala sekolah dalam meningkatkan pembelajaran guru adalah dengan berfokus pada kebutuhan peserta didik dan pengefektifan fungsi kepala sekolah sebagai pemimpin, supervisor, dan manajer di sekolah. Selain itu, juga peningkatan kompetensi kepala sekolah yang sesuai dengan era revolusi industri 4.0.
\end{abstract}

Kata Kunci: revolusi industri 4.0, kompetensi kepala sekolah, supervisi

Pendidikan di Indonesia telah memasuki era revolusi industri 4.0. Era ini ditandai dengan adanya digitalisasi dan serba otomatisnya segala sesuatu (Klinik Beasiswa LPDP UM, 2019). Revolusi industri 4.0 juga ditandai oleh dengan cyber fisik dan kolaborasi manufaktur. Era revolusi industri menggabungkan mesin, alur kerja, dan sistem, dengan menerapkan jaringan cerdas di sepanjang proses yang dimaksudkan untuk mengendalikan satu dengan lainnya secara mandiri. Dalam sambutan tertulis yang diberikan oleh Menteri Pendidikan dan Kebudayaan, Muhadjir Effendi, pada peringatan Hari PGRI ke 73 di tingkat provinsi Jawa Barat mengungkapkan bahwa perlu adanya peningkatan profesionalitas guru dan tenaga kependidikan agar sesuai dengan perkembangan revolusi industri. Triwiyanto, Suyanto \& Prasojo (2019:197) menyatakan istilah industri 4.0 muncul pada Hannover Fair tahun 2011 di Jerman, masa mendatang manajemen sekolah musti melakukan reformasi sebagai bagian menghadapi berbagai krisis.

Revolusi industri 4.0 menuntut guru untuk mampu memanfaatkan kemajuan teknologi informasi yang memang sangat cepat sehingga guru dapat meningkatkan kualitas belajar mengajar dan menyiapkan generasi yang unggul. Seiring dengan perubahan yang terjadi maka pembelajaran yang dilakukan guru kepada peserta didik juga harus berubah. Meningkatkan inovasi dan kreativitas guru diharapkan proses pembelajaran juga akan mampu memfasilitasi peserta didik sesuai dengan perubahan yang terjadi. 
Kualitas belajar mengajar yang dilakukan oleh guru tentu tidak lepas dari kontrol dan evaluasi kepala sekolah. Sebagai pemimpin di sekolah, kepala sekolah memiliki tugas untuk menyiapkan guru dalam peningkatan pembelajarannya.

Kepala sekolah sebagai seorang pemimpin di sekolah memiliki tugas dan peranan yang sangat penting serta strategis (Sobri, 2018). Salah satunya yakni tugas untuk menyiapkan guru dalam peningkaan kualitas pembelajaran. Sejalan dengan revolusi industri yang terjadi pada dunia pendidikan di Indonesia dan tugas kepala sekolah, maka kemampuan kepala sekolah juga harus semakin ditingkatkan dan dikuatkan. Oleh karena itu, diperlukan penyiapan kepala sekolah yang memadai dan sesuai dengan perubahan yang terjadi. Penyiapan ini bertujuan agar kepala sekolah mampu menjalankan tugas dan perannya dengan baik (Sobri 2018). Salah satu hal yang dapat dilakukan dalam menyiapkan kepala sekolah yang memadai sehingga dapat menciptakan guru yang memadai pula adalah dengan melakukan penguatan kompetensi kepala sekolah dalam kegiatan supervisi pembelajaran guru. Dan diharapkan kegiatan supervisi pembelajaran guru ini sesuai dengan revolusi industri 4.0.

Kepala sekolah yang siap dengan perubahan adaptif pendidikan pada era revolusi industri 4.0 akan siap membantu membimbing guru dan meningkatkan pembelajaran guru di sekolah. Oleh sebab itu, upaya kepala sekolah dalam rangka meningkatkan pembelajaran guru di era revolusi industri ini menarik untuk diteliti.

\section{METODE}

Penelitian dilakukan dengan menggunakan metode kualitatif jenis studi kasus. Pendekatan yang digunakan adalah teknik triangulasi data. Penelitian dilakukan untuk mengungkapkan fokus penelitian. Fokus utama penelitian ini adalah upaya kepala sekolah dalam meningkatkan pembelajaran guru di era revolusi industri 4.0. Dikarenakan data penelitian yang diperoleh berkaitan erat dengan pola kehidupan manusia maka diperlukan pengamatan yang mendalam untuk memahami fenomena secara komprehensif dan kontekstual.

Peneliti bertindak sebagai instrumen kunci dalam proses pengumpulan data penelitian agar data penelitian sesuai dengan kondisi di lapangan. Peneliti juga melakukan observasi partisipatif agar data penelitian yang diperoleh semakin baik. Agar tetap fokus pada fokus penelitian maka peneliti menggunakan panduan wawancara yang digunakan untuk menggali data dan memperdalam pengungkapan fokus penelitian. Panduan wawancara berupa jawaban terbuka. Jawaban dipaparkan oleh narasumber.

Penelitian dilakukan di SMPN 3 Peterongan Jombang. Pengumpulan data penelitian diperoleh melalui kegiatan wawancara, observasi, dan studi dokumentasi (Bogdan \& Biklen, 1985). Wawancara dilakukan dengan sumber data primer dan sumber data sekunder. Sumber data primer adalah kepala sekolah sedangkan sumber data sekuder adalah guru senior di sekolah yang direkomendasikan oleh kepala sekolah. Observasi yang dilakukan peneliti adalah observasi partisipatif melalui kegiatan supervisi di sekolah. Studi dokumentasi dilakukan peneliti pada dokumen instrumen supervisi sekolah dan perangkat pembelajaran guru di sekolah. Analisis data penelitian dilakukan melalui tahapan yang dikembangkan oleh Ulfatin (2014) yang dimodifikasi. Analisis data dimulai dengan mencatat catatan lapangan, mengumpulkan data, memberikan data kode dan pengklasifikasian data penelitian, dan menemukan temuan penelitian.

\section{HASIL DAN PEMBAHASAN}

SMPN 3 Peterongan merupakan sekolah negeri yang ada di Kabupaten Jombang. Sekolah ini unik sebab sekolah dengan status negeri namun berada pada naungan Yayasan Pondok Pesantren Darul Ulum Rejoso Peterongan Jombang. Sekolah ini memiliki guru dan tenaga kependidikan yang baik. Hal ini tampak pada semua guru sudah sarjana S1 sesuai bidangnya dan sudah ada yang sarjana S2. Begitu juga dengan guru kepondokan sekolah. Guru kepondokan yang ditugaskan mengajar di sekolah ini telah melalui tahap seleksi dan pembinaan dari Pondok Pesantren Darul Ulum Rejoso Peterongan. 
Karakteristik sekolah memiliki keunikah dan kekhasan. Berikut adalah karakteristik sekolah yang dituangkan dalam Tabel 1. Karakteristik SMPN 3 Peterongan.

Tabel 1. Karakteristik SMPN 3 Peterongan

\begin{tabular}{cll}
\hline No & \multicolumn{1}{c}{ Aspek } & \multicolumn{1}{c}{ SMPN 3 Peterongan } \\
\hline 1 & Status sekolah & Negeri di bawah Dinas Pendidikan dan Kebudayaan \\
2 & Binaan & Yayasan PP Darul Ulum Rejoso Peterongan \\
3 & Tahun berdiri & 1997 \\
4 & Pendiri & Pemerintah \\
5 & Akreditasi & A \\
6 & Alamat & Jl. Rejoso, Wonokerto Selatan, Peterongan Jombang \\
7 & Visi & Unggul dan berprestasi bertaraf internasional yang berlandas- \\
& & kan iman dan taqwa \\
8 & Rekrutmen guru dan kepala seko- & Dilakukan oleh Dinas Pendidikan. Guru kepondokan dilakukan \\
& lah & oleh Yayasan PP Darul Ulum Rejoso \\
\hline
\end{tabular}

Tabel 1. Karakteristik SMPN 3 Peterongan menunjukkan karakteristik dari sekolah. Keunikan dan kehasan sekolah tampak pada status sekolah yang berada pada naungan pondok pesantren. Adanya kondisi tersebut, maka proses pembelajaran yang ada di sekolah juga memiliki keunikan dibandingkan dengan sekolah negeri lainnya.

Proses pembelajaran di sekolah ini memadukan kurikulum nasional dan kurikulum pengayaan. Kurikulum pengayaan terdiri dari kurikulum kepesantrenan dan kurikulum aplikasi. Misalnya kurikulum pesantren yakni menambahkan 9 jam pelajaran pada masing-masing tingkatan peserta didik. Alokasi penambahan jam tersebut maka peserta didik akan mendapatkan materi dari kurikulum nasional, kurikulum muatan lokal, dan kurikulum kepesantrenan. Kurikulum aplikasi merupakan kekhasan yang ada di sekolah. Contohnya yakni 30 menit setiap hari sebelum memulai pembelajaran setiap hari anakanak harus membaca istighosah, membaca Al-Quran, dan membaca tahlil. Juga ada setiap sebulan sekali ada istighosah kubro yang diikuti oleh seluruh warga sekolah dan dilanjutkan adanya pembinaan dari majelis pimpinan pondok. Selain itu, peserta didik juga dibekali dengan pembelajaran Teknologi Informasi dan Komunikasi (TIK) dan sarana teknologi yang memadai untuk pembelajaran di sekolah.

Hasil penelitian yang dilakukan di SMPN 3 Peterongan Jombang menunjukkan bahwa upaya kepala sekolah dalam meningkatkan pembelajaran guru di Era Revolusi Industri 4.0 adalah dengan memperhatikan karakteristik pembelajaran, karakteristik guru, dan peningkatan kompetensi kepala sekolah yang sesuai dengan Era Revolusi Industri 4.0. Upaya kepala sekolah disesuaikan dengan kebutuhan dan lingkungan sekolah terutama kebutuhan peserta didik dalam mencapai tujuan belajar.

Kepala sekolah menganalisisi kebutuhan dan karakteristik pembelajaran di era 4.0 sehingga kepala sekolah dapat menentukan upaya yang sesuai untuk meningkatkan pembelajaran guru. Setelah tampak karakteristik pembelajaran yang sesuai dengan era 4.0, kepala sekolah selanjutnya memperhatikan karakteristik guru untuk menentukan pembinaan dan tindak lanjut yang dilakukan. Selain dengan upaya meningkatkan pembelajaran guru, kepala sekolah meningkatkan kompetensinya sehingga dapat sejalan dan mampu membina guru untuk menjadi lebih baik.

Pencapaian output SDM Indonesia di era revolusi industri 4.0 adalah bertujuan untuk mencapai relevansi pendidikan dan pekerjaan. Relevansi ini perlu disesuaikan dengan perkembangan IPTEK yang tetap memperhatikan aspek humanities, communication and design agar manusia tetap memiliki fungsi yang baik dalam lingkungan manusia (Arifin 2018). Upaya yang dilakukan oleh kepala sekolah sebagai pemimpin dalam pencapaian output SDM sekolah yang baik adalah dengan selalu memperbaiki program dan kebijakan-kebijakan sekolah. Hal ini tampak pada kegiatan kepala sekolah yang selalu memberikan kepemimpinan kepada guru-guru dalam memperbaiki pembelajaran (Sahertian, 2010).

Usaha kepala sekolah dalam menstimulus, mengkoordinasi dan membimbing secara kontinu pertumbuhan guru-guru di sekolah dikenal dengan kegiatan supervisi (Sahertian, 2010). Kegiatan 
tersebut dapat dilakukan secara individual maupun secara kolektif. Tujuan dari kegiatan supervisi ini adalah membantu guru mengembangkan kemampuan profesionalnya, mengontrol kegiatan belajar mengajar di sekolah, dan mendorong guru menerapkan kemampuannya dalam melaksanakan tugastugasnya (Sergiovanni, 1987) agar selalu update dan sesuai dengan perubahan.

Kepala sekolah perlu memperhatikan tren terkait pendidikan di era revolusi industri 4.0. Ada sembilan tren terkait dengan pendidikan 4.0 yang diadaptasi dari Hussin, (2018). Pertama, Pembelajaran dapat dilakukan kapan saja di mana saja. Alat $e$-Learning menawarkan peluang besar untuk pembelajaran jarak jauh dan serba mandiri. Pendekatan pembelajaran di kelas memainkan peran besar karena memungkinkan pembelajaran interaktif dilakukan, sementara bagian teoretis dapat dipelajari di luar waktu kelas. Kedua, pembelajaran disesuaikan untuk setiap kebutuhan peserta didik. Mereka diperkenalkan dengan tugastugas yang lebih sulit hanya setelah tingkat penguasaan tertentu tercapai. Praktik akan diberikan jika iguru melihat ada kebutuhan di dalamnya. Bantuan positif digunakan untuk memudahkan pengalaman belajar yang positif dan meningkatkan kepercayaan diri siswa tentang kemampuan akademik mereka sendiri. Strategi komuniaksi yang baik dengan peserta didik dapat mendukung peserta didik dalam mencapai tujuan dari kurikulum (Brett, dkk., 2018). Ketiga, peserta didik memiliki pilihan dalam menentukan bagaimana mereka ingin belajar. Meskipun hasil pembelajaran suatu mata pelajaran telah ditentukan oleh sekolah bertanggung jawab atas kurikulum, peserta didik masih bebas memilih alat atau teknik pembelajaran yang mereka sukai. Di antara opsi yang dapat diadopsi oleh guru untuk memungkinkan peserta didik menjadi kreatif dalam pembelajaran mereka adalah blended learning, membalik kelas dan pendekatan BYOD (Bring Your Own Device).

Keempat, peserta didik akan lebih banyak belajar berbasis pada proyek. Peserta didik diminta untuk menerapkan pengetahuan dan keterampilan mereka dalam menyelesaikan sebuah masalah. Dengan terlibat dalam proyek, mereka mempraktikkan keterampilan manajemen organisasi, kolaboratif dan waktu mereka yang berguna dalam karir akademik masa depan mereka.

Kelima, peserta didik akan lebih banyak mengalami pembelajaran langsung melalui pengalaman lapangan seperti magang, proyek bimbingan dan proyek kolaborasi. Kemajuan teknologi memungkinkan pembelajaran tertentu dapat dilakukan secara efektif, sehingga diharapkan dapat membuat lebih banyak ruang untuk memperoleh keterampilan yang melibatkan pengetahuan manusia dan interaksi tatap muka.

Keenam, peserta didik akan dihadapkan pada interpretasi data di mana mereka diminta untuk menerapkan pengetahuan teoretis mereka pada angka dan menggunakan keterampilan penalaran mereka untuk membuat kesimpulan berdasarkan logika dan permasalahan yang diberikan. Perhitungan matematika dan peramalan akan semakin mudah karena dilakukan oleh komputer.

Ketujuh, peserta didik akan dinilai secara berbeda dan platform penilaian konvensional akan mungkin menjadi tidak relevan atau tidak memadai. Pengetahuan faktual peserta didik dapat dinilai selama proses pembelajaran, sementara penerapan pengetahuan tersebut dapat diuji ketika mereka mengerjakan proyek-proyek mereka di lapangan.

Kedelapan, pendapat peserta didik akan dipertimbangkan dalam merancang dan memperbarui kurikulum. Masukan mereka membantu para perancang kurikulum mempertahankan kebutuhan kurikulum yang mutakhir dan bermanfaat. Kesembilan, peserta didik akan menjadi lebih mandiri dalam pembelajaran mereka sendiri, sehingga memaksa guru untuk mengambil peran baru sebagai fasilitator yang akan membimbing siswa melalui proses belajar mereka.

Sembilan tren pendidikan pada revolusi 4.0 menggeser tanggung jawab belajar utama dari instruktur (guru) ke peserta didik. Guru harus memainkan peran mereka untuk mendukung transisi dan tidak boleh menganggapnya sebagai ancaman bagi profesi guru konvensional. Selain itu, bekal agama juga sangat diperlukan. Oleh karena itu sekolah memasukkan kurikulum kepondokan untuk mengimbangi IPTEK dan IMTAQ peserta didik.

Upaya kepala sekolah meningkatkan pembelajaran guru di sekolah dapat dilakukan dengan pembinaan guru yang memperhatikan beberapa tren pembelajaran di era revolusi industri 4.0 dan kebutuhan serta lingkungan sekolah. Salah satunya adalah kepala sekolah dapat membangun kemitraan yang baik dengan guru di sekolahnya. Kemitraan antara kepala sekolah dan guru dalam kegiatan supervisi 
dibentuk secara terstruktur dan sangat membantu guru dalam menyelesaikan persoalan dengan posisi kepala sekolah sebagai pendorong utama perubahan (Allen, dkk., 2017). Selain itu, dapat pula dengan supervisi klinis. Supervisi klinis memungkinkan kepala sekolah untuk menyediakan yang diperlukan guru dalam perbaikan dan peningkatan kualitasnya (Li, dkk., 2018). Hubungan yang terjalin dilandasi oleh pandangan humanistis dalam supervisi. Dimana tanggung jawab atau peran guru yang sangat dominan dibandingkan peran dari supervisor atau kepala sekolahnya (Glickman, 1981). Sekali lagi yang perlu ditekankan bahwa upaya peningkatan pembelajaran di era revolusi industri 4.0 adalah membantu peserta didik dalam meraih tujuan pembelajaran dengan memperbaiki kualitas pendidik.

Revolusi industri 4.0 juga dikenal sebaga revolusi digital dan era disrupsi teknologi. Disebut sebagai revolusi digital sebab terdapat kemajuan dan campur tangan komputer dan otomatisasi pencatatan data di semua bidang. Dikatankan pula sebagai era disrupsi teknologi karena otomatisasi dan terhubungnya semua bidang yang akan membuat pergerakan industri dan persaingan kerja yang tidak linier (Hussin, 2018). Revolusi industri 4.0 dapat menggeser peran manusia sebagai salah satu karakteristiknya yakni adanya pengaplikasian kecerdasan buatan (artificial intelligence) (Imron, 2018).

Adanya peran manusia yang tergantikan oleh kecerdasan buatan dalam revolusi industri ini diharapkan bukan menjadi sebuah permasalahan. Revolusi industri 4.0 ini memungkinkan munculnya berbagai kelompok yang dapat mengembangkan inovasinya untuk menyelesaikan masalah yang telah ada sebelumnya (Ayu, tanpa tahun).

Era revolusi 4.0 menekankan pada digital economy, artificial intelleigence, big data, dan robotic, akhirnya juga berimbas pada dunia pendidikan. Revolusi industri 4.0 menuntut dunia pendidikan untuk dapat merekontruksi dan berubah. Perubahan dilakukan pada aspek pembelajaran. Perubahan dimulai dari penguatan kompetensi guru mengingat guru merupakan garda terdepan dalam pendidikan (Wahyuni, 2018). Guru dituntut untuk dapat merubah pembelajaran sesuai dengan tuntuan dunia menghadapi revolusi industri 4.0. Sebagai contoh, guru mampu memanfaatkan kemajuan teknologi yang semakin cepat dan kaya informasi untuk meningkatkan kualitas proses pembelajaran (Wahyuni, 2018). Selain itu, diharapkan juga mampu untuk menyiapkan generasi emas Indonesia yang berkualitas dan berkompeten, memperbaiki kualitas hidup, berkontribusi pada pembangunan nasional, dan mampu menjawab tantangan global (Arifin, 2018).

Guru yang harus semakin mampu menyiapkan generasi medatang harus selalu memperbaiki diri pula. Salah satu Ayat dalam Al-Quran yang berbunyi "sesungguhnya Allah tidak akan mengubah keadaan suatu kaum sebelum mereka mengubah keadaan mereka sendiri (QS. Ra-Ra'd:11) menjelaskan bahwa manusia perlu berubah untuk memperbaiki kehidupannya. Salah satu bentuk perubahan yang terjadi pada dunia pendidikan adalah perubahan pembelajaran yang dilakukan oleh guru. Perubahan tersebut merupakan upaya memperbaiki kualitas seorang guru sehingga mampu dan berkompeten seiring perkembangan zaman.

Perubahan pembelajaran guru tentunya tidak lepas dari sosok kepala sekolah sebagai supervisor guru. Kepala sekolah sebagai supervisor harus mampu mengarahkan dan membentuk guru untuk mampu mengintegrasikan berbagai perkembangan teknologi dalam proses pembelajaran (Ayu, tanpa tahun dan Hussin, 2018). Dengan harapan pemelajaran akan semakin menarik dan juga lebih efektif sesuai dengan cara penyampaian pada generasi di era revolusi industri atau dikenal dengan generasi Z (Hussin, 2018).

Karakteristik pembelajaran guru yang diharapkan di Era Revolusi Industri 4.0 adalah yang adaptif, inovatif, memanfaatkan teknologi dengan baik, dan berpusat pada peserta didik (Latip, 2018). Pembelajaran guru mampu menyesuaikan dengan perubahan kebutuhan peserta didik agar sesuai dengan perkembangan teknologi dan lingkungan. Pembelajaran guru inovatif dan kreatif sehingga pembelajaran lebih menarik dan peserta didik terlatih untuk mengasah kemampuannya. Pembelajaran yang memanfaatkan perkembangan teknologi dan komunikasi dengan baik. Dan pembelajaran yang berpusat pada kebutuhan dan perkembangan peserta didik. beberapa karakteristik pembelajaran yang diharapkan terjadi di Era Revolusi Industri 4.0 saat ini.

Upaya perubahan yang terjadi pada dunia pendidikan khususnya perubahan pembelajaran guru juga tidak dapat dilepaskan dari sosok kepala sekolah meskipun kepala sekolah bukan lagi memiliki 
tugas pokok untuk mengajar melainkan tugas pokoknya dalah sebagai pemimpin dan pengelola sekolah (Permendikbud Nomor 6 Tahun 2018). Dengan tugas sebagai pemimpin dan pengelola satuan pendidikan, tentu kepala sekolah akan berkewajiban mewujudkan guru yang berprestasi dan semakin baik dalam perkembangannya. Selain itu, kepala sekolah juga harus mampu menjadi pemimpin yang efektif, menginspirasi, memimpin pengembangan dan implementasi visi bersama untuk integrasi teknologi dalam upaya mempromosikan keunggulan sekolah dan mendukung transformasi dalam organisasi (Thannimalai dan Arumugam, 2018).

Agar kepemimpinan kepala sekolah berjalan efektif maka kepala sekolah harus menjalankan lima fungsi utamanya (Nawawi, 2008 dalam Sobri, 2018). Lima fungsi tersebut adalah fungsi pengambilan keputusan dan harus selalu menngunakan data dalam proses pengambilan keputusan (Stronge, dkk., 2013), instruktif atau memberikan instruksi, konsultatif atau menjadi pendengar dan pemberi saran yang baik, partisipatif atau mampu mempengaruhi anggota organisasi sekolah, dan delegatif atau memiliki kewenangan dalam mendelegasikan tugas. Kelima fungsi tersebut harus dijalankan secara konsisten oleh kepala sekolah (Sobri, 2018).

Kepala sekolah yang efektif selain dengan konsisten menjalankan lima fungsinya di atas, juga harus memahami, membangun, dan menjaga visi sekolah. Seorang kepala sekolah yang efektif dan sukses menjalankan tugasnya harus memiliki visi yang jelas. Memiliki gambaran yang jelas mengenai sekolah yang dipimpinnya (Stronge, dkk., 2013). Dalam mencapai tujuan sekolah kepala sekolah melibatkan seluruh anggota sekolah. Selain itu, kepala sekolah juga harus mampu membangkitkan kemampuan guru untuk menjadi pemimpin dan melibatkan guru dalam pengambilan keputusan (Stronge, dkk., 2013).

Kepala sekolah di era revolusi industri 4.0 menjadikan kesuksesan peserta didiknya sebagai titik pusat kegiatan pembelajaran dan pekerjaan (Stronge, dkk., 2013). Oleh karena itu, kepala sekolah mengajak guru untuk memberikan perhatian khusus terhadap pengajaran, kurikulum, dan penguasaan kompetensi peserta didik. Selain itu, kepala sekolah juga harus mudah ditemui di sekolahnya (Stronge, dkk., 2013). Sehingga, kontrol dan evaluasi sekolah dapat dengan mudah dilakukan dan berkelanjutan.

Kompetensi kepala sekolah telah diatur dalam Permendiknas Nomor 13 Tahun 2007. Pada aturan Permendiknas tersebut tampak bahwa kompetensi kepala sekolah terdiri dari kompetensi kepribadian, manajerial, kewirausahaan, supervisi, dan sosial. Kompetensi kepala sekolah adalah pengetahuan, keterampilan, dan nilai dasar yang dimiliki oleh kepala sekolah. Sebagai upaya memiliki dan memenuhi kompetensi kepala sekolah, maka dalam menjalankan tugasnya seorang kepala sekolah harus memahami hakikat kepemimpinan yang itu menjadi tugasnya (Sobri, 2018).

Penguatan kompetensi kepala sekolah dapat dilakukan dengan pengembangan keprofesian berkelanjutan. Pengembangan Keprofesian Berkelanjutan adalah program dan kegiatan peningkatan pengetahuan, keterampilan, dan sikap profesional kepala sekolah yang dilaksanakan berjenjang, bertahap, dan berkesinambungan terutama untuk peningkatan manajemen, pengembangan kewirausahaan, dan supervisi kepada guru dan tenaga kependidikan (Permendikbud Nomor 6 Tahun 2018 dan Southworth, 2002 dalam Nirmala, 2018).

Salah satu kompetensi yang harus ditingkatkan oleh kepala sekolah dalam upaya pengembangan keprofesian berkelanjutan adalah kompetensi supervisi. Kompetensi ini menekankan bahwa seorang kepala sekolah dapat membina guru menjadi guru yang profesional (Sobri, 2018). Kepala sekolah dalam melaksanakan supervisi perlu memahami dan menggunakan pendekatan dan teknik supervisi yang sesuai. Selanjutnya kepala sekolah menindaklanjuti kegiatan supervisi dalam upaya peningkatan profesionalisme guru (Permendiknas Nomor 13 Tahun 2007).

Kepala sekolah yang memiliki kompetensi supervisi yang baik nantinya akan dapat membina guru dan mewujudkan peningkatan profesionalitas guru dalam pembelajaran. Kepala sekolah dapat bekerjasama dengan pengawas sekolah untuk memperdalam pemahaman akan supervisi dan meningkatkan profesionalitas guru (Sobri, 2018). Sehingga, program dan tujuan dari sekolah juga akan dengan mudah dicapai serta peningkatan kualitas pendidikan di era revolusi industri juga akan tercapai.

Untuk mengembangkan dan meningkatkan kualitas pendidikan, kepala sekolah dapat melakukan tugas dan peran secara profesional dalam kegiatan berikut (Haris, dkk., 2018): memberikan umpan balik 
tentang kinerja guru; mengidentifikasi kebutuhan untuk pengembangan staf; mengidentifikasi potensi untuk promosi; melakukan pemeriksaan jaminan kualitas serta memastikan motivasi dan moral guru dan memberikan dukungan dan bimbingan profesional kepada para guru. Selain itu, kepala sekolah memastikan bahwa lingkungan profesional mendukung proses belajar mengajar. Tujuan akhir dari kegiatan ini adalah untuk meningkatkan kualitas pengajaran dan pembelajaran. Ini berarti bahwa kepala sekolah perlu memainkan peran sebagai perencana; penyelenggara; pemimpin; pembantu; evaluator, penilai, motivator, komunikator, dan pembuat keputusan.

\section{SIMPULAN}

Kesimpulannya adalah penguatan upaya kepala sekolah dalam meningkatkan pembelajaran guru di era revolusi industri 4.0 dilaksanakan dengan berbagai langkah dan pertimbangan. Langkah tersebut bertujuan untuk membantu guru mengembangkan kemampuan profesionalnya, mengontrol kegiatan belajar mengajar di sekolah, dan mendorong guru menerapkan kemampuannya dalam melaksanakan tugas-tugasnya. Upaya peningkatan pembelajaran juga harus sejalan dengan perubahan yang terjadi pada dunia pendidikan di era revolusi industrri 4.0. Kepala sekolah harus bisa mewujudkan sosok guru yang sesuai dengan harapan pendidikan di era 4.0 melalui pembinaan guru yang berorientasi pada kebutuhan dan outcome peserta didik. Upaya juga dilakukan oleh kepala sekolah untuk meningkatkan kemampuannya sehingga mampu membina guru untuk menjadilebih baik. Saran penelitian ini secara umum adalah dengan adanya perubahan yang terjadi pada dunia pendidikan dan perbaikan guna menjawab tantangan global, upaya peningkatan pembelajaran disesuaikan dengan pergeseran yang terjadi. Saran khusus penelitian ini adalah untuk peneliti selanjutnya agar mengembangkan dan menyempurnakan penelitian guna perbaikan ilmu pengetahuan di masa mendatang.

\section{DAFTAR RUJUKAN}

Allen, J. M., dkk. 2017. Project Evidence: Responding to the Changing Professional Learning Needs of Mentors in Initial Teacher Education. Australian Journal of Teacher Education, 42(7), (online). Dari (https://files.eric. ed.gov/fulltext/EJ1151158.pdf), diakses 5 Maret 2019.

Ayu, N. A. K. Tanpa tahun. Peluang Social Innovation dalam Revolusi Industri 4.0. Yogyakarta: Forbil Institute. (Online), dari (http://forbil.org/manage/statics/publication/27/Forbil_Ebook_Series_Nov-II_Peluang_ Social_Innovation_dalam_Revolusi_Industri_4.0.pdf), diakses 5 Maret 2019.

Bogdan, R. Dan Biklen, S. K. 1982. Qualitatif Research for Education: And Introduction to Theory and Methods. Boston: Allyn \& Bacon Inc.

Brett, P. D., dkk. 2018. Learning the Words: Supervising Teachers and the Language of Impact in an Initial Teacher Education Programme. Australian Journal of Teacher Education, 43 (8), (online). Dari (https://files.eric. ed.gov/fulltext/EJ1190336.pdf), diakses 5 Maret 2019.

Glickman, Carl. D. 1981. Developmental Supervision: Alternative Practices for Helping Teachers Improve Instruction. Educational Resources Information Center, (online). Dari (https://files.eric.ed.gov/fulltext/ ED208487.pdf), diakses 29 September 2018.

Haris, Ikhfan., dkk., 2018. School Supervision Practices in the Indonesian Education System; Perspectives and Challenges. Journal of Social Studies Education Research, 9 (2), (online). Dari (https://files.eric.ed.gov/ fulltext/EJ1181981.pdf), diakses 5 Maret 2019.

Hussin. A. A. 2018. Education 4.0 Made Simple: Ideas for Teaching. International Journal of Education \& Literacy Studies, 6 (3), (online). Dari (https://files.eric.ed.gov/fulltext/EJ1190812.pdf), diakses 5 maret 2019.

Imron, Arifin. 2018. Nilai-Nilai Humanistik dalam Peningkatan Mutu Pendidikan di Era Globalisasi dan Revolusi Industri 4. SNAMPe, (online). Dari (ojs.unm.ac.id/semapfip/article/download/6095/pdf_41), diakses 5 maret 2019.

Klinik Beasiswa LPDP UM. Siap Menuju Generasi 4.0. Minggu, 3 Maret 2019.

Latip,A. 2018. 4 Kompetensi Guru di Era Revolusi Industri 4.0. Kompasiana. (Online) dari http://www.kompasiana. 
com/altip/5bfcab25aeebe161c772f98f/4-kompetensi-guru-di-era-revolusi-industri-4-0?page=1.

Li, Dan., dkk. 2018. Supervising Asian International Counseling Students: Using the Integrative Developmental Model. Journal of International Students, 8 (2), (online). Dari (https://files.eric.ed.gov/fulltext/EJ1180966. pdf), diakses 5 Maret 2019.

Nirmala. 2018. Implementasi Kurikulum 2013 dalam Mendorong Kepemimpinan Pembelajaran Kepala Sekolah. SNAMPe, (online). Dari (ojs.unm.ac.id/semapfip/article/download/6095/pdf_41), diakses 5 maret 2019.

Permendikbud Nomot 6 Tahun 2018 tentang Penugasan Guru sebagai Kepala Sekolah.

Permendiknas Nomor 13 Tahun 2007 tentang Standar Kepala Sekolah/Madrasah.

Sahertian, Piet. 2010. Konsep Dasar dan Teknik supervisi Pendidikan dalam Rangka Pengembangan Sumber Daya Manusia. Jakarta: Rineka cipta.

Sergiovanni, Thomas J. 1987. The Principalship: A Reflective practice perspective. United States of America: Allyn and Bacon, Inc.

Sobri. A. Yusuf. 2018. Penguatan Kompetensi Kepala Sekolah dalam Meningkatkan Kualitas Pendidikan. SNAMPe, (online). Dari (ojs.unm.ac.id/semapfip/article/download/6095/pdf_41), diakses 5 Maret 2019.

Stronge, J. H., dkk. 2008. Alih Bahasa Oleh Siti Mahyuni. Kualitas Kepala Sekolah yang Efektif. Jakarta: ASCD.

Thannimalai, Raamani dan Arumugam. 2018. The Influence Of Principals' Technology Leadership And Professional Development On Teachers' Technology Integration In Secondary Schools. Malaysian Journal of Learning and Instruction, 15 (1), (online). Dari (https://files.eric.ed.gov/fulltext/EJ1185796.pdf), diakses 5 Maret 2019.

Triwiyanto, Teguh., Suyanto, \& Prasojo, Lantip Diat. (2019).The Thoughts of Ki Hadjar Dewantara and Their Implications for School Management in the Industrial Era 4.0. International Journal of Innovation, Creativity and Change, 5(4), 197-208.

Ulfatin, Nurul. 2015. Metode Penelitian Kualitatif di Bidang Pendidikan: Teori dan Aplikasinya. Malang: Media Nusa Creative.

Wahyuni. 2018. Peningkatan Kompetensi Guru Menuju Era Revolusi Industri 4.0. pusat Penelitian Badan Keahlian DPR RI, 10 (24), (online). Dari (http://berkas.dpr.go.id/puslit/files/info_singkat/Info\%20SingkatX-24-II-P3DI-Desember-2018-218.pdf), diakses 5 Maret 2019. 